\title{
Analysis and Interpretation of the New Foreign Investment Law of the People's Republic of China
}

\section{Min Zhao*}

The Foreign Investment Law of the People's Republic of China has attracted great attention worldwide since its adoption on March 15, 2019, and will come into force on January 1, 2020. This law can be regarded as the most important law of China in the field of foreign investment since China's accession to the World Trade Organization. The legislation process of the foreign investment law of the People's Republic of China has expressed the strong will of the Chinese legislature in amending and perfecting the legal system. The implementation of this law will positively impact the future investment environment of China. This article analyses the background and evolution of the legislation procedure, the highlights and features of the law compared with earlier related laws in the field of foreign investment of China, and the impact and insufficiency of the law, together with the issues following the implementation of the law.

Keywords: Foreign Investment Law, Foreign-invested Enterprises, Protection, Promotion

* Lecturer of Shanghai University of Finance and Economics; Visiting Scholar of CCLS Queen Mary University of London. Ph.D. (Nan Kai Univ.). ORCID: https://orcid.org/0000-00017068-9358. The author may be contacted at: zhminsh@163.com/Address: 36 (601), No. 281 HongXiangRoad, Song Jiang District, Shanghai, China. All the websites cited in this article were last visited on August 9, 2019. 


\section{INTRODUCTION}

On March 15, 2019, the Second Session of the Thirteenth National People's Congress passed the Foreign Investment Law of the People's Republic of China (hereinafter Foreign Investment Law). ${ }^{1}$ The law comes into force on January 1, 2020, containing six chapters with forty-two articles. ${ }^{2}$ As the first basic law in the field of foreign investment in China, the Foreign Investment Law guarantees the principle of consistency of foreign and domestic investment outside the negative list, ${ }^{3}$ attaches more importance to the promotion and protection of foreign investment, and lays the foundation for further expansion of China's opening-up policy. ${ }^{4}$ With the implementation of the Foreign Investment Law, China is showing its strong will to improve investment rules and meet international standards in the field of intellectual property rights and to create a fair and transparent competitive environment.

\section{Promulgation and Evolution of the Foreign INVESTMENT LAW}

\section{A. Promulgation of the Foreign Investment Law}

Since the reform and opening-up policy began in the late 1970s, China has gradually formed a legal system of foreign investment that mainly includes the Law of the People's Republic of China on Sino-Foreign Equity Joint Ventures, 5 on Foreign Capital Enterprise ${ }^{6}$ and on Sino-Foreign Contractual Joint Ventures ${ }^{7}$ (hereinafter the three laws on foreign-invested enterprises). This legal system provided effective legal guarantee for expanding opening-up and actively utilizing foreign capital. By the end of December 2018, there were about 960,000 foreign-invested enterprises in China, and the actual utilisation of foreign capital exceeded a total of USD 2.1 trillion. ${ }^{8}$

According to the statistics of the United Nations Conference on Trade and Development ("UNCTAD"), since 1992, China's actual use of foreign capital has ranked first in developing countries for 27 consecutive years. ${ }^{9}$ Since 1998, the actual use of foreign capital in high-tech industries has increased 16 fold and the number of regional headquarters and $\mathrm{R} \& \mathrm{D}$ centres invested by transnational 
corporations in China has exceeded 2000. ${ }^{10}$ Global foreign direct investment ("FDI") has been an important force in promoting China's economic and social development. ${ }^{11}$

However, at the legislative level, there is still a lack of support for the basic legal framework in the field of foreign investment. In recent years, China has faced a new situation in opening-up and utilising foreign capital. Because the three laws on foreign-invested enterprises have repetitive or inconsistent with other laws, it is difficult to meet the needs of building a new and open economy system. China is urgently required to formulate a unified basic law on foreign capital under the new situation. $^{12}$

Statistics show that global FDI fell by more than 19 percent from USD 1.47 trillion in 2017 to USD 1.2 trillion in 2018, while FDI in developed countries dropped sharply by nearly 40 percent or about USD 451 billion. ${ }^{13}$ Unlike the global statistics, in China, the actual use of foreign capital exceeded USD 142 billion in 2018, a new high record of 3 percent more than in 2017. ${ }^{14}$ Among them, the actual utilisation of foreign capital in the manufacturing industry reached USD 41.2 billion in 2018, an increase of 22.9 percent over the previous year, ${ }^{15}$ and a number of major foreign capital projects in the manufacturing sector settled/ established in China. For example, Tesla (US) and BMW (Germany) have made great efforts to increase investment in China: Tesla's global super-factory of USD 5 billion in Shanghai took less than half a year from the announcement to the start of construction, ${ }^{16}$ while BMW extended an agreement with its Chinese partners to 2040 and decided to increase its investment by Euro 3.6 billion. ${ }^{17}$

In the context of the Sino-US trade conflict that began in early 2018, the US has accused China of forcibly requiring foreign investors to transfer advanced technology according to some FDI laws and other laws, or administrative licences. In order to avoid the misinterpretation, the related articles in some laws on foreign investment have been removed during the legislation of the Foreign Investment Law of the People's Republic of China. ${ }^{18}$

For the past 40 years of reform and opening-up, the manufacturing industry has grown in an open environment, and the pace of opening-up for the manufacturing industry has accelerated. In 2018, two negative lists about foreign investment access were revised and promulgated. The overall opening of aircraft, ship and automobiles manufacturing all have a timetable, while restrictions on foreign 
investment in the smelting of rare earth and other mineral resources have been abolished. At present, in the stage of market access, the general manufacturing industry has been fully opened to the outside world. Although the automobile industry is not fully open until now, a timetable has been drawn up to achieve full opening to foreign investment by 2022 at the latest. ${ }^{19}$ According to Cui Fan, professor at the University of Foreign Economics and Trade, speeding up the introduction of foreign investment laws at the 40 -year-old stage of reform and opening-up is conducive to promoting the formation of a new pattern of openingup. $^{20}$

At the end of 2018, when deploying the economic work of 2019, China attached great importance to the new situation. It is significant for China to promote the transformation from 'flow-oriented' opening-up to 'rule-based' opening-up. At the same time, there is an urgent need to relax market access; fully implement the management system of Post-Entry National Treatment plus Negative List; protect the legitimate rights and interests of foreign investment in China (especially intellectual property rights); and allow more sectors to implement sole proprietorship. ${ }^{21}$ The core of 'rule-based' opening-up is to bring the international criterion, which corresponds to the market rules prevailing in the major economies of the world. The legislative purpose of the Foreign Investment Law is based on the rule-based opening-up of foreign investment in China. ${ }^{22}$

In this course, the Chinese legislature asked foreign chambers of commerce and foreign-invested enterprises whether the Foreign Investment Law directly responded to their demands and concerns. For example, the law stipulates that all of China's policies to support the development of national enterprises shall equally apply to foreign-invested enterprises. ${ }^{23}$ China guarantees foreign-invested enterprises will participate in government procurement activities through fair competition in accordance with related law. ${ }^{24}$ The Foreign Investment Law was passed at an unprecedented rate because China wanted to convince a safe business environment for foreign enterprises and investors.

\section{B. Evolution Procedure for the Foreign Investment Law}

The Third Plenary Session of the Eleventh Central Committee of the Communist Party of China, held in December 1978, opened China to the outside world. In response, the Second Session of the Fifth National People's Congress on July 1, 
1979 adopted the Law of the People's Republic of China on Sino-Foreign Equity Joint Ventures; the Fourth Session of the Sixth National People's Congress on April 12, 1986 adopted the Law of the People's Republic of China on Foreign Capital Enterprises; and the First Session of the Seventh National People's Congress on April 13, 1988 adopted the Law of the People's Republic of China on Sino-Foreign Contractual Joint Ventures. ${ }^{25}$ The successive promulgation of the three laws on foreign-invested enterprises marked the progress of China's opening-up to the outside world in accordance with the law and established a management system of case-by-case examination and approval in the field of foreign investment.

In 2001, China revised the three laws on foreign-invested enterprises conforming to the global trade rules in order to promote China's accession to the WTO. Although this revision and subsequent legislation and reform in the administrative field have not changed the management system of case-by-case examination and approval in the field of foreign investment, they have gradually standardised the examination and approval system and process in the field of foreign investment; deleted the provisions requiring foreign-invested enterprises to give priority to domestic procurement; and removed the requirement of submitting the operation and construction plans of the enterprises to the competent authorities. These changes accelerated the pace of China's opening to the outside world. ${ }^{26}$

The Third and Fourth Plenary Sessions of the Eighteenth Central Committee of the Communist Party of China put forward clear requirements for the unification of domestic and foreign capital laws and the improvement of foreign-investment related laws and regulations. Since October 2013, China has been experimenting with the pre-entry national treatment plus negative list management model throughout the country with a view to gradually replacing the traditional case-bycase examination and approval model. ${ }^{27}$

With the transformation of reform and opening-up from market- driven to innovation-driven, the idea of "emphasising supervision over services" has been unable to meet the vigorous development of various industries in China and the demand of foreign investors for 'innovation management.' On January 19, 2015, the Ministry of Commerce promulgated the Foreign Investment Law (hereinafter Draft for Comments 2015) to solicit opinions from the public. ${ }^{28}$ The draft presented a framework for a unified and systematic regulation of basic laws in the field of 
foreign investment. It also proposed a new management system for the field of foreign investment - pre-entry national treatment plus negative list - which is in an attempt to create a stable, transparent and predictable legal environment for foreign investors in China. However, as the provisions of the Draft for Comments 2015 were rather complicated, involving such as 'agreement control' and rules of the national security review system, it was not promulgated. ${ }^{29}$

In April 2015, the State Council of China approved to open three free trade zones Guangdong, Tianjin and Fujian. Since 2016, the three laws on foreigninvested enterprises have been further amended. In combination with the Interim Measures of Record-keeping Management for Establishment and Change of Foreign-invested Enterprises promulgated and revised by the Ministry of Commerce, the new foreign-invested enterprises management system was gradually established, combining the universal record-keeping system with the examination and approval system under the negative list. ${ }^{30}$

The new management systems in the field of foreign investment with negative lists are gradually approaching to a management system of the complete preentry national treatment plus negative list. ${ }^{31}$ On September 3, 2016, the Standing Committee of the National People's Congress promulgated a decision on amending four laws, including the Law on Foreign Capital Enterprises, in order to change the relevant examination and approval items into the pattern of records management in the form of law. ${ }^{32}$

There had been no unified law yet in the field of foreign investment until the Legislative Work Plan of the Standing Committee of the National People's Congress for 2018. ${ }^{33}$ The Ministry of Commerce, the State Development and Reform Commission, and the Ministry of Justice consulted 72 relevant central units, such as the Central Finance Office, the Ministry of Foreign Affairs, the Ministry of Finance and the People's Bank of China. ${ }^{34}$

On December 26, 2018, the National People's Congress published the Foreign Investment Law (hereinafter Draft for Comments 2018) on its official website to solicit public opinion. ${ }^{35}$ Compared with the Draft for Comment 2015, the new draft 'slimmed' its provisions from 170 articles to 39 articles, which were inclined to be principled. Many controversial issues, such as 'agreement control' and rules of the national security review system, were deleted. It was clearly stipulated that the management system of pre-entry national treatment plus a negative list should be 
implemented for foreign investment. Emphasis was placed on the promotion and protection of foreign investment, while principled provisions were made based on foreign investment management systems, such as an information reporting system, operator concentration review system and national security review system. ${ }^{36}$

At the Seventh Session of the Standing Committee of the Thirteenth National People's Congress, the Standing Committee of the National People's Congress published the draft on the website of the Chinese National People's Congress to solicit opinions from the provinces, autonomous regions, municipalities, and some universities and research institutions. ${ }^{37}$ Meanwhile, the Constitution and Law Committee of the National People's Congress, Financial and Economic Committee, and Standing Committee's Legal Work Committee jointly held a symposium to hear the views of the relevant departments of the Central Government, enterprise associations, experts as well as some foreign chambers of commerce and foreign-invested enterprises. All sides generally agreed with the formulation of the Foreign Investment Law, which was an important measure to improve the system of foreign-investment related laws and regulations. Here, suggestions for revision and improvement were put forward. ${ }^{38}$

On January 10, 2019, the Constitution and Legal Committee of the National People's Congress convened a meeting. According to the deliberations of the members of the Standing Committee and the opinions of all parties, the draft was considered article by article. ${ }^{39}$

On January 30, 2019, the Eighth Session of the Standing Committee of the Thirteenth National People's Congress adopted the proposal of the Standing Committee of the National People's Congress to submit the draft Foreign Investment Law for deliberation. It decided to submit the draft Foreign Investment Law to the Second Session of the Thirteenth National People's Congress for deliberation. ${ }^{40}$ On March 8, 2019, the draft Foreign Investment Law was submitted to the Second Session of the Thirteenth National People's Congress for deliberation.

On March 15, 2019, the Second Session of the Thirteenth National People's Congress passed the Foreign Investment Law. The law will come into force on January $1,2020^{41}$ with 42 articles ( 6 chapters). Today, each article seems not only to hit the key point directly, but also to be of high value. 


\section{Highlights of the Foreign Investment LAw}

\section{A. Clarifying the Basic Position of the Law}

The Foreign Investment Law is the basic law of unified management and the promotion of foreign investment. It no longer takes the organizational form of enterprises as the normative object. That is to say, organizational forms and business activities of foreign-invested enterprises directly and uniformly apply laws and regulations to different market entities. For example, the establishment of foreign-invested limited liability companies is uniformly governed by the Company Law so there is no need to consider the three laws for foreign-invested enterprises to solve the inconsistencies between the old foreign capital laws and the Company Law. ${ }^{42}$

The three laws on foreign-invested enterprises will be repealed on January 1, 2020 when the Foreign Investment Law takes effect. ${ }^{43}$ In this case, those foreign-invested enterprises established before the implementation of the Foreign Investment Law can retain their original organizational form for five years after the new law is implemented. ${ }^{44}$

The Foreign Investment Law focuses on foreign investment access and other important matters. Specific details will be left to the implementation regulations formulated in the near future. ${ }^{45}$

\section{B. Redefining the Concept of Foreign Investment}

The concept of foreign investment has been redefined in the Foreign Investment Law as:

Investment activities of foreign natural persons, enterprises or other organizations (hereinafter 'foreign investors') directly or indirectly within the territory of China, including the following: (1) foreign investors that set up foreign-invested enterprises in China alone or jointly with other investors; (2) foreign investors that obtain shares, equities, property shares, or other similar rights and interests of enterprises within the territory of China; (3) foreign investors that invest in new projects in China alone or jointly with other investors; and (4) other investment activity prescribed by laws, administrative regulations or the State Council. Foreign-invested enterprises mentioned in the Foreign Investment Law refer to enterprises that are wholly or partly invested by foreign investors and registered within the territory of China under Chinese laws. ${ }^{46}$ 


\section{Fully Adopting the System of Pre-Entry National Treatment Plus Negative List} The Special Management Measures for Foreign Investment (Negative List) issued by the Development and Reform Commission in June 2018 has reduced the restrictive content of foreign investment access to 48 items, which greatly decreases the number of restrictive foreign investment sectors/industries. ${ }^{47}$ On December 21, 2018, the National Development and Reform Commission and the Ministry of Commerce jointly issued a new negative list of market access (2018 edition) applicable to all projects, including domestic invested and foreign invested. $^{48}$ It is foreseeable that the entry threshold for foreign investment will be further lowered, so that in the near future, a foreign-invested project may involve the following procedures:

(a) For those industries not included in the negative list: they just need to record in business departments, get the industry-related administrative licensing (if applicable) and the enterprise establishment registration.

(b) For those industries appearing in the restriction category in the negative list: they need the approval of the Development and Reform Commission and the commercial department. They may need to apply for the relevant administrative licence (if applicable) and register for the establishment of enterprises.

(c) Whether or not the industries are included in negative list or not, some specific projects may need to be considered for concentration review and safety review of foreign investment, depending on the circumstances. ${ }^{49}$

\section{Promotion of Foreign Investment}

Chapter II (Articles 9-19) of the Foreign Investment Law stipulates the investment promotion, mainly from five aspects. First, this chapter clarifies that all policies of the state to support the development of domestic enterprises shall be equally applicable to foreign-invested enterprises. ${ }^{50}$ Article 9 shows that China will offer a fairer and equal investment environment to the foreign investors. Second, when formulating laws, regulations and rules relating to foreign investment, Chinese legislatures shall listen to opinions and suggestions from foreign-invested enterprises. Normative and adjudicative documents related to foreign investment shall, according to law, be made public in a timely manner. ${ }^{51}$ The law includes that the state establishes and improves the service system for foreign investment, and it provides consultation and services on laws, regulations, policies and measures on 
investment projects for foreign investors and foreign-invested enterprises. ${ }^{52}$

Third, foreign-invested enterprises can participate in government procurement activities on an equal footing with domestic enterprises. Products and services provided by foreign-invested enterprises within the territory of China are treated equally in government procurement in accordance with the law. ${ }^{53}$ Fourth, foreigninvested enterprises may, in accordance with the law, finance through the public offering of stocks, corporate bonds and other securities. ${ }^{54}$ According to this article, foreign capital can participate in the competition of government procurement as fairly as domestic capital.

Fifth, the people's government at all levels and relevant departments shall, in accordance with the principles of facilitation, efficiency and transparency, simplify procedures, improve efficiency, optimise government services and further improve the level of foreign investment services. ${ }^{55}$

\section{E. Protection of Foreign Investment}

To protect the legitimate rights and interests of foreign investors, Chapter III (Articles 20-27) of the Foreign Investment Law provides comprehensive and principled provisions from four aspects. First, Chapter III strengthens the protection of property rights of foreign-invested enterprises. Article 20 stipulates that the state does not expropriate foreign investment. Under extraordinary circumstances, the state may expropriate and requisition the investment of foreign investors in accordance with the law and for the needs of public interest. Such expropriation and requisition shall be conducted in accordance with legal procedures; timely and reasonable compensation shall be given. ${ }^{56}$ Further, foreign investors' capital contribution, profits, capital gains, assets disposal income, intellectual property licence fees, legally obtained damages or compensation, liquidation proceeds, etc., may be freely remitted overseas in RMB or foreign exchange according to law. ${ }^{57}$ The state protects the intellectual property rights of foreign investors and foreigninvested enterprises, protects the legitimate rights and interests of intellectual property rights holders and related rights holders, and holds intellectual property rights infringers legally accountable in accordance with the law. ${ }^{58}$

Second, Chapter III strengthens the constraints on the formulation of normative documents concerning foreign investment. ${ }^{59}$ The Foreign Investment Law regulates that administrative organs and their staff members shall keep 
confidential the business secrets of foreign investors and foreign-invested enterprises they receive in the course of performing their duties and shall not disclose or illegally provide them to others. ${ }^{60}$ The people's government at all levels and their relevant departments shall comply with the provisions of laws and regulations in formulating normative documents concerning foreign investment. Unless authorized by laws and administrative regulations, they shall not derogate from the legitimate rights and interests of foreign-invested enterprises or increase their obligations; set forth conditions for market access and exit; and interfere with normal production and operation of foreign-invested enterprises. ${ }^{61}$

Third, Chapter III promotes local governments to abide by their promises. Article 25 provides that local people's governments at all levels and their relevant departments shall honor their commitments on policies and contracts concluded in accordance with the law. If policy commitments or contractual agreements need to be changed for state interests and public interests, they shall be conducted in accordance with the statutory authority and procedures, and foreign investors and foreign-invested enterprises shall be compensated for the losses they suffered accordingly. ${ }^{62}$

Fourth, Chapter III improves the complaint mechanism for foreign-invested enterprises. Article 26 stipulates that the state should establish a complaint mechanism for foreign-invested enterprises, co-ordinate and improve major policies and measures in the complaint of foreign-invested enterprises, and promptly solve problems. If a foreign-invested enterprise or its investors believe the administrative acts of the administrative organs and their staff infringe on its legitimate rights and interests, they may apply for administrative reconsideration and bring administrative proceedings in accordance with the law, in addition to applying for co-ordinated settlement through the complaint mechanism of the foreign-invested enterprise. ${ }^{63}$ Foreign investors and foreign-invested enterprises can establish and voluntarily participate in chambers of commerce and associations to safeguard their legitimate rights and interests. ${ }^{64}$

\section{F. The Administration of Foreign Investment}

First, to implement the management system of the post-entry national treatment plus negative list, foreign investors should not invest in areas prohibited by the negative list and in areas where investment is restricted; foreign investors shall 
meet the prescribed conditions for investment. For those areas not included in the negative list, things should be managed in accordance with the principle of consistency between domestic and foreign investments. ${ }^{65}$ At present, China's restrictive measures on foreign investment have been reduced to 48 items. Those arrangement in the Foreign Investment Law undoubtedly protect the openness and transparency of China's investment environment on a legal level. ${ }^{66}$

Second, the Foreign Investment Law accords with relevant laws and regulations. Article 29 stipulates that the approval and filing of foreign investment projects shall be carried out in accordance with the relevant provisions of the state. The relevant licensing procedures shall be carried out in the industries and fields where foreign investors need to obtain licences according to the law. ${ }^{67}$ Forms of organization, organizational structures and activities of foreign-invested enterprises shall be governed by the provisions of the Company Law and the Law of the Partnership Enterprise of the People's Republic of China (hereinafter Partnership Enterprise Law). ${ }^{68}$ Production and business activities of foreigninvested enterprises, as well as taxation, accounting and foreign exchange matters, also should be handled in accordance with relevant laws, administrative regulations and relevant provisions of the state. ${ }^{69}$

Third, the Foreign Investment Law provides that the state should establish a foreign investment information reporting system. The content and scope of the information reporting should be determined in accordance with the principles of necessity and strict control. ${ }^{70}$ Foreign investors or foreign-invested enterprises should submit investment information to the relevant commercial departments through the enterprise registration system and the enterprise credit information publicity system. $^{71}$ The investment information, which can be obtained through the information sharing of different departments, shall not be required to report repeatedly. ${ }^{72}$

Fourth, to safeguard national security, the system of foreign investment security review has been stipulated in principle. It clarifies that the decision of the security review should be the final one.

\section{G. Other Concerns/Concerned Questions}

Article 8 of the Foreign Investment Law provides for trade unions, chambers of commerce and associations. It improves the protection of the legitimate rights 
and interests of employees of foreign-invested enterprises. ${ }^{74}$ In Chapter VI, the law stipulates that if any country or region takes discriminatory prohibitions, restrictions or other similar measures against China with respect to investment, China may take retaliatory measures against the country or region in accordance with the actual situation.

This provision conforms to the principle of reciprocity in international economic and trade relations. This provision also conforms to China's existing international obligations in investment. It is conducive to promoting the principle of non-discrimination as a basic principle of international investment.

The Foreign Investment Law also includes the provisions in the financial sectors. ${ }^{76}$ If the state has other regulations for the specific financial issues, however, such regulations shall be followed. The existing foreign investment management and statistical system contain the financial and non-financial fields. After implementing the new Foreign Investment Law, China is asked to integrate both management and statistics when taking into account the particularity of the financial industry.

With the implementation of the Foreign Investment Law, relevant laws and regulations concerning foreign investment will be changed. Also, a brand-new foreign investment management system will be formed and gradually improved, which will promote China to a higher level of investment liberalisation and facilitation.

\section{Contrasts between the Foreign InVESTMent LAW AND THReE LAwS ON Foreign-INVESTED ENTERPRISES}

\section{A. Emphasising Equal Treatment between Domestic and Foreign-invested Enterprises}

The Foreign Investment Law has been adopted to further expand China's openingup program; actively promote foreign investment; protect the legitimate rights and interests of foreign investment; standardize the management of foreign investment; and promote the formation of a new pattern of comprehensive opening-up and the healthy development of the socialist market economy. ${ }^{77}$ Compared with 
the earlier three laws on foreign-invested enterprises, "Drawing up this Law in accordance with the Constitution" has been added. ${ }^{78}$ The relevant provisions of the management system of pre-entry national treatment plus negative list were improved, amended and perfected to embody the spirit of "treating domestic and foreign-invested enterprises equally and fairly." ${ }^{, 79}$ Further, to establish and maintain a fair and competitive market environment, the provisions on the antimonopoly review of mergers and acquisitions by foreign investors have been provided in the law.

\section{B. More Protection for Intellectual Property Rights and More Emphasis on Mutual Benefit and Reciprocity}

The Foreign Investment Law has established the basic institutional framework for foreign investment under the new pattern of comprehensive opening-up and implemented the management system of pre-entry national treatment plus a negative list. ${ }^{80}$ The law clarifies that all state policies supporting the development of domestic enterprises shall equally apply to foreign-invested enterprises, which strengthens the legal protection for the legitimate rights and interests of foreign investment and improves the liberalization and internationalization of the Chinese market. $^{81}$

To facilitate the establishment of a conducive business environment and attract more high-quality foreign investment, China should create a better business atmosphere and reduce restrictions on foreign investment by implementing the Foreign Investment Law. The provisions of the law involve many issues, including intellectual property protection and protection of foreign capital. Generally speaking, the law promises to treat foreign enterprises operating in China on an equal footing with domestic enterprises but reserves the right to "conduct security review of foreign investment affecting or possibly affecting national security."

\section{Attaching Great Importance to the Promotion of Foreign Investment}

Compared with the three laws on foreign-invested enterprises, the Foreign Investment Law pays more attention to promoting and protecting foreign investment. The law does not regulate the organizational behaviour of enterprises. It contains a large number of provisions regulating the Chinese government's activities of delegation, supervision and service, which will help create a better investment environment 
for foreign investors. ${ }^{83}$ The scope of regulation is limited to foreign investors and their investment activities, so that the organizational forms and business activities of foreign-invested enterprises shall be directly controlled by laws and regulations applicable to different types of market entities. In this way, the inconsistencies between the three laws of foreign investment, and the Company Law and other laws and regulations have been eliminated. ${ }^{84}$

When the Foreign Investment Law enters into force, foreign-invested enterprises shall be established in the forms of limited liability companies, limited companies, partnerships and other enterprises in accordance with the Company Law, the Partnership Enterprise Law and other relevant laws. The governance structure and activity criteria of the enterprises shall be established and improved in accordance with the aforementioned laws. Annex shows the details of the changes at the end of this paper.

\section{The Impact Of The Foreign InVestment LAW ON FOREIGN-INVESTED ENTERPRISES}

Under the Foreign Investment Law, there is a five-year transition period for those enterprises established according to the three laws on foreign-invested enterprises. ${ }^{85}$ Many problems remain to be solved in practice due to the lack of relevant detailed rules, as discussed below.

\section{A. Application of Laws}

During the five-year transition period, how should those foreign-invested enterprises willing to retain their original organizational forms, governance structures and rules of activities solve the problem of applying laws? ${ }^{86}$ Should they apply the current Foreign Investment Law or the three laws on foreign-invested enterprises that will have been repealed? For those foreign-invested enterprises that cannot reach a consensus during the transition period and cannot adjust their organizational form, governance structure and rules of activities in accordance with the new law, or cannot complete the adjustment within the transition period, what should be done to regulate the problems? ${ }^{87}$ Similar issues need to be clarified in the implementing regulation. 


\section{B. Adjustment of Corporate Governance Structure}

After the implementation of the Foreign Investment Law, companies established according to the three laws on foreign-invested enterprises will need to adjust and standardise their governance structure, such as amending their articles of association, adjusting the power organ of the company to the shareholder meeting, expanding the powers of the shareholder meeting, establishing rules of procedure and voting procedures of the shareholders' meeting, and installing supervisors or board of supervisors. In addition, those enterprises will need to adjust the functions and powers of the board of directors, relevant clauses such as mode of election of directors, voting mode, etc. ${ }^{88}$ Furthermore, in practice, enterprises also will need to agree on the transfer rules of equity, profit distribution and other important matters of the company.

Because all the adjustments will involve fundamental interests, the corresponding work may not be simple. Then, there would be a new game between Chinese and foreign shareholders on the adjustment of governance structure and related rules. ${ }^{9}$ If there are disputes or even deadlocks between the parties, how should the law be applied to handle these problems? Relevant provisions should be thus adopted shortly.

In addition, with the abolition of the three laws on foreign-invested enterprises (the supporting implementing regulations and rules are also expected to be abolished), the contractual joint venture contracts and equity joint venture contracts will lose their original position as controversial documents, and return to the role of shareholder agreements.

\section{Recovering Investment in Advance and Distribution of Residual Property}

In accordance with the three laws on foreign-invested enterprises and their implementing regulations, if agreed in a Sino-foreign joint enterprise contract that all fixed assets will be owned by the Chinese partners at the expiration of the cooperative period, then the foreign partners can recover the investment in advance during this period. ${ }^{92}$ Moreover, equity joint venture or contractual joint venture parties shall be allowed to distribute the residual assets of the enterprise according to the agreement. ${ }^{93}$

According to the Company Law, shareholders of all parties may agree on the proportion and mode of profit distribution separately without consideration of 
the proportion of capital contribution, so as to realise the "recovery of investment in advance" by some shareholders. ${ }^{94}$ Because the Company Law stipulates that the residual property of the company is allocated according to the proportion of capital contribution, ${ }^{95}$ however, there might be an inconsistency between existing contracts or articles of association and the stipulation of the Company Law about the distribution of residual property. The inconsistency might cause problems after the expiration of the transition period. In this regard, there should still be supporting provisions to give clear guidance to the corresponding treatment. ${ }^{96}$

\section{Total Investment and Foreign Debt Line}

In contrast to domestic-invested enterprises, foreign-invested enterprises have a different concept of 'total investment. ${ }^{97}$ For the management of foreign debt quota of foreign-invested enterprises, the foreign debt line is generally applicable to the mode of "the difference between actual investment and registered investment." That is, the upper limit of foreign debt borrowed by foreign-funded enterprises can be determined according to the difference between total investment and registered capital. According to the Notice of the People's Bank of China [2017] No. 9 (hereinafter No. 9) on the Macro-prudential Management of Full-caliber Cross-border Financing, ${ }^{99}$ the amount of foreign debt of enterprises determined by the macro-prudential management model will be twice that of net assets. No. 9 stipulates that within the first year of its issue, foreign-invested enterprises or foreign-invested financial institutions can choose either the original mode or the macro-prudential mode prescribed in the latest No. 9 for their implementation of the amount of foreign debt.

After the transition, foreign-invested financial institutions shall apply the macro-prudential mode compulsorily, while foreign-invested enterprises shall be determined by the People's Bank of China and the State Administration of Foreign Exchange on the basis of specific performance evaluation. ${ }^{100}$

Today, there are no specific regulations on the cross-border financing management of foreign-invested enterprises after the transition period. Even after the implementation of the Foreign Investment Law, there is still room for the traditional management mode of determining the foreign debt quota according to the difference between the investment and registered capital before the formal regulation on the application of macro-prudential mode to cross-border financing 
of foreign-invested enterprises is promulgated. The 'total investment' still has significance and should not be cancelled prematurely. ${ }^{101}$

\section{Linking with Current Laws and Systems AND FOLLOW-UP IMPLEMENTATION}

\section{A. Linking with the Current Laws and Systems}

\section{Linking with international treaties and agreements}

Article 4 of the Foreign Investment Law stipulates that if international treaties and agreements concluded or acceded to by China have more preferential provisions on access treatment for foreign investors, those provisions can be implemented. ${ }^{102}$ This regulation co-ordinates the national treatment given to foreign investors under the Foreign Investment Law and the super-national treatment that might be given to foreign investors of specific countries or regions in international treaties and agreements. ${ }^{103}$ It not only resolves the potential conflicts between domestic legislation and international treaties and agreements, but also retains sufficient flexibility for China's opening-up and foreign policy. ${ }^{104}$

2. Linking with the Company Law, Partnership Enterprise Law and other laws Article 31 of the Foreign Investment Law stipulates that forms of organisation, organisation structures and activities of foreign-invested enterprises shall be governed by the provisions of the Company Law and the Partnership Enterprise Law. ${ }^{105}$

As mentioned above, the Foreign Investment Law stipulates that foreigninvested enterprises established in accordance with the three laws on foreigninvested enterprises may continue to retain their original forms of organisation for up to five years after the implementation of this new law. ${ }^{106}$ In contrast to the method of differentiating supervision measures according to different organizational forms in the three laws on foreign-invested enterprises, the Foreign Investment Law unifies the "organizational form and organisation structures" with the Company Law and the Partnership Enterprise Law. ${ }^{107}$ On one hand, the unification implements the national treatment for foreign investors. On the other hand, it also avoids conflicts with the Company Law, Partnership Enterprise Law 
and their subsequent amendments. ${ }^{108}$

Foreign-invested enterprises established earlier should pay attention to the timely adjustment of their organizational forms in accordance with the provisions of the Company Law or the Partnership Enterprise Law. For example, Sinoforeign equity joint ventures should establish the shareholder meeting, board of directors and board of supervisors in accordance with the provisions of the Company Law. ${ }^{109}$ Additionally, the following content should be clarified in future implementation measures formulated by the State Council: (1) specific ways to adjust the organizational form, organisation structure and activity criteria of the foreign-invested enterprises established under the three laws on foreign-invested enterprises in accordance with the Company Law and the Partnership Enterprise Law, such as the establishment of 'three boards' and the transfer of equity rights pursuant to three laws on foreign-invested enterprises; and (2) how to deal with non-timely adjustment after the expiration of the five-year transition period. ${ }^{110}$

\section{Linking with the Anti-Monopoly Law}

The Foreign Investment Law stipulates that foreign investors who merge Chinese enterprises or participate in the concentration of undertakings shall be subject to examining the concentration of undertakings in accordance with the provisions of the Anti-Monopoly Law. ${ }^{111}$ Such provisions show that in the field of foreign investment, the concentration of operators should also be examined, but the scope and process of examination should be stipulated by a more advanced AntiMonopoly Law. ${ }^{112}$

\section{Linking with the Current Information Reporting System}

Article 34 of the Foreign Investment Law stipulates that the state shall establish an information reporting system for foreign investment. Foreign investors or foreign-invested enterprises shall submit investment information to the relevant commercial departments through the enterprise registration system and the enterprise credit information publicity system. The content and scope of the foreign investment information report shall be determined in accordance with the principle of necessity; the investment information that can be obtained through the interdepartmental information sharing system shall not be required to be submitted again. ${ }^{113}$ 
These provisions clearly define the ways and scope of information submission. The way of submission through the enterprise registration system and the enterprise credit information publicity system should be connected to the "single window, single form" ${ }^{, 14}$ of foreign-invested enterprises' business record and industrial and commercial registration. The principle of 'necessity' and the principle of "excepting information sharing" effectively alleviate the burden of information delivery for foreign investors and foreign-invested enterprises. ${ }^{115}$

\section{Linking with the National Security Review}

Unlike the Draft for Comment 2015, which attempted to establish a national security review system in the field of foreign investment through twenty-seven articles in a whole chapter, the final Foreign Investment Law only stipulates the "foreign investment security review system" in principle. The specific scope and process of the review should be regulated by the "Notice of the General Office of State Council on Establishment of Security Review System for Foreign Investors' Mergers and Acquisitions of Domestic Enterprises" Implementation Measures of Foreign Investment National Security Review in Free Trade Pilot Area." ${ }^{117}$ Combining the various situations of foreign investment stipulated in Article 2 of the Foreign Investment Law, it can be reasonably inferred that the national security review system in the field of foreign investment in the future may refer to the free trade area model and apply to all kinds of foreign investment, not only foreign mergers and acquisitions.

It should be noted that whether the stipulation of "The security review decision made in accordance with the law is final" ${ }^{118}$ in the final Foreign Investment Law represents the same idea of "no administrative reconsideration and administrative litigation for the national security review decision made in accordance with this chapter" in Draft for Comment $2015^{119}$ remains to be further observed. Although the national security review is a special administrative function of the government and may involve more confidential information related to the national strategy, it may become a 'black hole' in the field of foreign investment if it is completely exempted from administrative reconsideration and administrative litigation in accordance with the Draft for Comment 2015. How to link the national security review with administrative reconsideration and administrative litigation conditionally will be an important issue in the future construction of the national security review system 
in the field of foreign investment. ${ }^{120}$

\section{B. Key Issues in the Follow-up Implementation of the Foreign Investment Law}

The Foreign Investment Law undoubtedly will give more powerful basic legal protection to foreign investors in China and greatly promote the development of FDI and foreign-invested enterprises. Because many provisions in the law are more general, however, the specific details for its future progress require government departments to promulgate further implementation rules and regulations as soon as possible. Therefore, the actual effect of the law still needs to be tested in future practice. $^{121}$

Gao Feng, the spokesman for the Ministry of Commerce, stated at a regular meeting on March 21, 2019 that to ensure the smooth implementation of the Foreign Investment Law, the Ministry of Commerce is actively promoting the formulation of supporting laws and regulations. ${ }^{122}$ In this regard, the existing regulations on foreign investment management are also comprehensively cleaned up. Gao Feng elaborated: "In this process, we will actively and earnestly listen to the opinions and suggestions of foreign-invested enterprises and other relevant parties." ${ }^{123}$

\section{Promoting Opening Up of the Field of Industry}

China will promote the opening-up of the field of industry as follows. First, it will fully implement the management model of pre-entry national treatment plus negative list and implement the promised opening-up policies in the fields of aircraft, ships, automobiles and telecommunications. Second, there will be further research on measures for a deeper and wider opening-up of telecommunications industries, such as expanding the scope of encouraging foreign investment and accelerating the landing of major foreign investment projects. Third, there will be further remission to industrial policies and adherence to the principle of equal treatment for the development of domestic and foreign-invested enterprises in China. $^{124}$

The promulgation of the Foreign Investment Law will reassure foreign investors and foreign-invested enterprises of more solid legal protection to safeguard their legitimate rights and interests. This, in turn, will make China's foreign investment environment more open, fair, transparent, legalised, internationalised and 
convenient.

\section{Further Development of Implementation Rules}

Given the significance of the changes, matching and cohesion problems in the specific operation process might rise when the Foreign Investment law comes into effect on January 1, 2020. It is thus necessary to formulate specific regulations for implementing the Foreign Investment Law to make the legal provisions clearer and more operational. Also, all parties should accurately understand and interpret the core meaning and the connotation of each article, so as to facilitate implementation. In the process of implementation, efforts should be made to refine and supplement the relevant supporting systems. As the current provisions of the Foreign Investment Law are relatively concise, it is necessary to promulgate the implementation rules as soon as possible. Moreover, China should encourage to formulate laws for the "Belt and Road Initiative" or the "Going Out" of Chinese domestic enterprises.

At the legislative level, the cohesion of relevant supporting systems in the field of foreign investment should be strengthened. Foreign investment involves a wide range of aspects, such as liquidation and settlement, taxation, foreign exchange and labour. It needs a lot of investigation work. This work cannot be delayed too long, otherwise the implementation of the Foreign Investment Law will stall. At the implementation level, meanwhile, the Foreign Investment Law and other related laws such as corporate law, securities law and bankruptcy law should be firmly connected. ${ }^{125}$

Because the Foreign Investment Law attaches more importance to the promotion and protection of foreign investment, the scale of reform and breakthroughs are considerable. It is thus necessary to introduce matching rules and management measures to ensure the effective implementation of the Foreign Investment Law. The Anti-Monopoly Law should also prohibit foreign-invested enterprises from abusing their dominant position in the market more strongly. ${ }^{126}$

\section{Strengthening Communication and Co-ordination between Judicial} and Administrative Organs

Liu Xiaoyun, president of the Shanghai Higher People's Court, proposed at the Second Session of the Thirteenth National People's Congress that after the Foreign 
Investment Law goes into effect, communication and coordination between judicial organs and administrative authorities should be strengthened linking with law enforcement. ${ }^{127}$ For example, the Foreign Investment Law stipulates that enterprises originally established under the three laws on foreign-invested enterprises will have a five-year transition period. Tens of thousands of foreigninvested enterprises will be then required for re-registration. This poses a challenge for not only the relevant government authorities, but also the courts to hear disputes concerning foreign-invested enterprises. The courts and administrative authorities therefore need to strengthen their communication to ensure the correct application of the law. ${ }^{128}$

In addition, some experts have pointed out that, on one hand, grass-roots operating departments should actively understand and familiarise themselves with international rules, learn from foreign practices to facilitate foreign-invested enterprises, improve the management mechanism of credit rating agencies, break administrative monopolies and achieve a state of survival of the fittest. On the other hand, the relevant departments of the central authorities or their local organisations, such as the "one bank and two sessions," ${ }^{, 29}$ should also put down their position and take the initiative to participate in the construction of "one network operation" ${ }^{, 130}$ of local governments, so as to serve foreign-invested enterprises well. ${ }^{131}$

\section{Conclusion}

The Foreign Investment Law will better protect and attract foreign investment. The law provides more regulation of the behaviour of the government. The government should issue a series of regulations and documents in accordance with the spirit of this law to protect the rights and interests of foreign investors, such as how to make the information complaint mechanism open, transparent and effective. In the near future, a series of relevant regulations and documents will be introduced to ensure the smooth implementation of the Foreign Investment Law. ${ }^{132}$ A new version of the reduced negative list of foreign investment access will launch in 2019 and a new Patent Law will introduce a punitive damages mechanism relating to the infringement of intellectual property. ${ }^{133}$ Opening-up measures in China 
will continue to be pushed forward in 2019, but they are often not launched in a package. These measures come out annually or even quarterly, but in retrospect, they will bring about great changes beyond imagination.

\section{Annex: Comparison between the Foreign Investment Law and the Three Laws on Foreign-invested Enterprises}

\begin{tabular}{|c|c|c|}
\hline Items & $\begin{array}{l}\text { Rules of the three laws on } \\
\text { foreign-invested enterprises }\end{array}$ & $\begin{array}{l}\text { Post-implementation of the } \\
\text { Foreign Investment Law }\end{array}$ \\
\hline Power organs & $\begin{array}{l}\text { Board of directors (Sino-Foreign Equity Joint } \\
\text { Ventures) or Joint Management Committee (Sino- } \\
\text { Foreign Contractual Joint Ventures) or shareholder } \\
\text { meeting (Foreign Capital Enterprise) }\end{array}$ & Shareholder meeting \\
\hline $\begin{array}{l}\text { Term of office } \\
\text { of directors }\end{array}$ & Four years (Sino-Foreign Equity Joint Ventures) & Three years \\
\hline $\begin{array}{l}\text { Election of } \\
\text { directors }\end{array}$ & Direct appointment of investors & $\begin{array}{l}\text { The non-staff representative } \\
\text { directors shall be elected and } \\
\text { replaced by the shareholder } \\
\text { meeting, and the staff } \\
\text { representative directors shall } \\
\text { be elected democratically by } \\
\text { the company }\end{array}$ \\
\hline Quorum & $\begin{array}{l}\text { The minimum attendance at meetings of the board } \\
\text { of directors (Sino-Foreign Equity Joint Ventures) } \\
\text { or the joint management committee (Sino-Foreign } \\
\text { Contractual Joint Ventures) is two-thirds }\end{array}$ & $\begin{array}{l}\text { No requirement; the articles } \\
\text { of association of the company } \\
\text { stipulate their own }\end{array}$ \\
\hline $\begin{array}{l}\text { Voting on } \\
\text { matters } \\
\text { of importance }\end{array}$ & $\begin{array}{l}\text { Resolutions on major matters of Sino-Foreign } \\
\text { Equity Joint Ventures must be unanimously } \\
\text { adopted by the directors (or committees) present at } \\
\text { the meeting }\end{array}$ & $\begin{array}{l}\text { Adopted by more than two- } \\
\text { thirds of the shareholders with } \\
\text { voting rights }\end{array}$ \\
\hline $\begin{array}{l}\text { Legal } \\
\text { representative }\end{array}$ & $\begin{array}{l}\text { Chairman of the board of directors (Sino-Foreign } \\
\text { Equity Joint Ventures) or director of the joint } \\
\text { management committee (Sino-Foreign Contractual } \\
\text { Joint Ventures) }\end{array}$ & $\begin{array}{l}\text { Chairman, executive director or } \\
\text { manager }\end{array}$ \\
\hline Supervisor & $\begin{array}{l}\text { No regulations (Sino-Foreign Equity Joint Ventures, } \\
\text { Sino-Foreign Joint Ventures) }\end{array}$ & $\begin{array}{l}\text { Supervisors or board of } \\
\text { supervisors shall be established }\end{array}$ \\
\hline $\begin{array}{l}\text { Limitations on } \\
\text { equity transfer }\end{array}$ & Agreed by other shareholders unanimously & $\begin{array}{l}\text { Agreed by more than half of the } \\
\text { other shareholders }\end{array}$ \\
\hline
\end{tabular}




\begin{tabular}{|c|c|c|}
\hline $\begin{array}{l}\text { Profit } \\
\text { distribution }\end{array}$ & $\begin{array}{l}\text { Distribution in proportion to capital contribution } \\
\text { (Sino-Foreign Equity Joint Ventures) }\end{array}$ & $\begin{array}{l}\text { Can be allocated in a prescribed } \\
\text { proportion }\end{array}$ \\
\hline $\begin{array}{l}\text { Recover } \\
\text { investment in } \\
\text { advance by } \\
\text { foreign } \\
\text { investors }\end{array}$ & $\begin{array}{l}\text { If the Chinese and foreign partners agree in the } \\
\text { joint venture contract that all the fixed assets of } \\
\text { the joint venture shall be owned by the Chinese } \\
\text { partners upon the expiration of the term of co- } \\
\text { operation, they may stipulate in the contract } \\
\text { the method for the foreign partners to recover } \\
\text { their investment in advance within the term of } \\
\text { co-operation. (Sino-Foreign Contractual Joint } \\
\text { Ventures) } \\
\text { If it has been agreed in the joint venture contract } \\
\text { that when the term of co-operation expires, then all } \\
\text { fixed assets of the contractual joint venture shall } \\
\text { be owned by the Chinese partner free of charge. } \\
\text { During the period of co-operation, the foreign } \\
\text { partner may, on the basis of allocation according } \\
\text { to investment or co-operation conditions, agree in } \\
\text { the joint venture contract to expand the proportion } \\
\text { of income distribution of the foreign partner } \\
\text { and recover its investment first (Rules for the } \\
\text { Implementation of the Law on Sino-Foreign } \\
\text { Contractual Joint Ventures). }\end{array}$ & $\begin{array}{l}\text { After paying for the liquidated } \\
\text { expenses, staff salaries, social } \\
\text { insurance expenditure and } \\
\text { statutory compensation, taxes } \\
\text { owed and debts of the company, } \\
\text { the residual property of a } \\
\text { limited liability company shall } \\
\text { be allocated according to the } \\
\text { proportion of shareholder capital } \\
\text { contribution, and the residual } \\
\text { property of a joint stock limited } \\
\text { company shall be allocated } \\
\text { according to the proportion of } \\
\text { shares held by shareholders }\end{array}$ \\
\hline $\begin{array}{l}\text { Withdrawal } \\
\text { of funds }\end{array}$ & $\begin{array}{l}\text { Reserve Fund, Employee Award and Welfare } \\
\text { Fund, and Enterprise Development Fund }\end{array}$ & $\begin{array}{l}\text { Legal Accumulation Fund and } \\
\text { Optional Accumulation Fund }\end{array}$ \\
\hline $\begin{array}{l}\text { Aggregate } \\
\text { investment }\end{array}$ & Clear agreement required & No requirement \\
\hline
\end{tabular}

Source: Compiled by the author. 


\section{REFERENCES}

1. See the Decree of the President of the People's Republic of China, No. 26. (15 Mar. 2019), available at http://www.npc.gov.cn/npc/xinwen/2019-03/15/content_2083625.htm.

2. See Foreign Investment Law of the People's Republic of China [中华人民共和国外商投资法 ] (promulgated by Nat'l People's Cong., Mar. 15, 2019; effective Jan. 1, 2020), available at http://www.npc.gov.cn/npc/xinwen/2019-03/15/content_2083532.htm [hereinafter Foreign Investment Law].

3. Article 4 of the Foreign Investment Law stipulates: "The State gives national treatment to foreign investment outside the negative list', thus officially establishing the system of 'preentry national treatment plus a negative list management for foreign investment."

4. Chapter II of the Foreign Investment Law (arts. 9-19) concern investment promotion for foreign investment. For example, foreign-invested enterprises can equally enjoy state policies concerning the support of enterprise development. The legislature should solicit opinions from foreign-invested enterprises when formulating related laws. Foreigninvested enterprises have equal access to government procurement. Foreign-invested enterprises may finance through the public offering of stocks, corporate bonds and other securities.

5. The Law of the People's Republic of China on Sino-Foreign Equity Joint Ventures was enacted to expand international economic co-operation and technological exchanges and allow foreign companies, enterprises, and other economic organizations or individuals to jointly establish joint ventures with Chinese companies, enterprises or other economic organizations within the territory of China and with the approval of the Chinese government, in accordance with the principles of equality and mutual benefit. The law was adopted at the Second Meeting of the Fifth National People's Congress on July 1, 1979, and the latest amendment was made at the Twenty-Second Meeting of the Standing Committee of the Twelfth National People's Congress on September 3, 2016.

6. The Law of the People's Republic of China on Foreign Capital Enterprises was enacted to allow foreign enterprises and other economic organizations or individuals to set up foreigninvested enterprises in China and to protect the legitimate rights and interests of foreigninvested enterprises. The law was adopted on April 12, 1986 at the Fourth Meeting of the Sixth National People's Congress, and the latest version was passed on September 3, 2016 at the Twenty-Second Meeting of the Standing Committee of the Twelfth National People's Congress.

7. The Law of the People's Republic of China on Sino-Foreign Contractual Joint Ventures [hereinafter Law on Sino-Foreign Contractual Joint Ventures] was formulated to promote foreign enterprises and other economic organizations or individuals to co-sponsor Sinoforeign co-operative enterprises with enterprises or other economic organizations within the territory of China in accordance with the principles of equality and mutual benefit. This 
law was adopted at the First Meeting of the Seventh National People's Congress on April 13, 1988. The newest amendment was passed at the Thirteenth Meeting of the Standing Committee of the Twelfth National People's Congress on November 4, 2017.

8. Zixun Zhou, Interpretation of Foreign Investment Law [解读外商投资法], CHINA ECONOMIC TiMES [中国经济时报], 11 Mar. 2019, available at http://jjsb.cet.com.cn/show_506856.html.

9. United Nations Conference on Trade and Development (UNCTAD), World Investment Report 2018: Investment and New Industrial Policies, at 4, available at https:/unctad.org/ en/PublicationsLibrary/wir2018_en.pdf.

10. Id.

11. China Statistical Yearbook 2018, available at http://www.stats.gov.cn/tjsj/ndsj/2018/ indexeh.htm.

12. Huanyou Liu, Liberalization of International Investment and Improvement of China's Foreign-funded Enterprise Law, Legality Vision 4 (2016).

13. UNCTAD, Investment Trends Monitor (Jan. 2019), available at https://unctad.org/en/ PublicationsLibrary/diaeiainf2019d1_en.pdf.

14. Id.

15. Qing Zhao, Speeding Up of the Legislative Process of the New Foreign Investment Law [ 新外商投资法立法进程提速], CAP. MKT \& RULE L. FAREN MAG. [法人] 60 (2019).

16. Shanghai Municipal People's Government, Tesla's First Overseas Super Factory Settled in Shanghai, Press Release (July 1, 2018), available at http://www.shanghai.gov.cn/nw2/ nw2314/nw2315/nw4411/u21aw1325482.html.

17. German Carmaker Eyes Greater Control of Unit While Boosting Overall Margins, Fin. Times, available at https://www.ft.com/content/9a3ee15a-cced-11e8-b276b9069bde0956.

18. Article 3 of the Law of People's Republic of China on Foreign Capital Enterprise stipulates that the state encourages the establishment of the enterprises with foreign capital that export their products or are technologically advanced. Article 4 of the Law of People's Republic of China on Sino-Foreign Contractual Joint Ventures stipulates the same rule. Article 5 of the Law of People's Republic of China on Sino-Foreign Equity Joint Ventures stipulates that the technology or equipment contributed by any foreign party as investment shall be truly advanced and appropriate to the needs of China. The above articles are actually not about imperative technology transfer but have always been misinterpreted that way. So the Foreign Investment Law has removed such stipulations.

19. PRC National Development and Reform Commission, 'Expanding Opening-up to Promote High Quality Development of Automobile Industry,' Press Release, (July 2018), available at $\mathrm{http}: / / w z s . n d r c . g o v . c n / w s t z / w s t z g k / 201807 / \mathrm{t} 20180712$ 892338.html.

20. Meichen Liu, The New Chinese Foreign Investment Law and Its Implication on Foreign Investors, 38 NorthWestern J. INT'L L. \& Bus. XXX, 287 (2018).

21. Section 6 of the Economic Work Conference of China (2018), available at http://cpc. 
people.com.cn/n1/2018/1222/c64094-30481845.html.

22. Junchen Liu, Deputy Director of the Legal Work Committee of the Standing Committee of the National People's Congress, The Legislative Purpose of Foreign Investment Law Highlights Two Words: Promotion and Protection, available at https://www.chinacourt. org/index.php/article/detail/2019/03/id/3751808.shtml.

23. Foreign Investment Law art. 9, $₫ 1$.

24. Id. art. 16.

25. Dianguo Wang, Opening to the Outside World requires the Legislation in Advance, the website of PRC Ministry of Commerce China General Office (Secretariat of China International Trade Representative), available at http://bgt.mofcom.gov.cn/article/ ggkf/201901/20190102830198.shtml.

26. Yixuan Chen, Foreign Investment Law: Termination of Case-by case Approval System [外 国投资法: 逐案审批时代终结], 2 CAPITAL SHANGHAI [上海国资] 34 (201).

27. In 2103, the government of Shanghai promulgated Special Management Measures for Foreign Investment in Shanghai Free Trade Test Zone (Negative List). In March, 2016, China formulated Draft Negative List for Market Access (Trial version), firstly implemented in Tianjin, Shanghai, Fujian and Guangdong. In 2017, the pilot area was expanded to 15 provinces and municipalities. In December 2018, China promulgated Negative List for Market Access (2018 Edition), which marks the full implementation of the negative list system for market access in China, available at https://baijiahao.baidu. $\mathrm{com} / \mathrm{s} ? \mathrm{id}=1620874230647510056 \& \mathrm{wfr}=$ spider\&for $=\mathrm{pc}$.

28. PRC Ministry of Commerce, Openly Solicit opinions on Foreign Investment Law of the People's Republic of China (Draft for Opinions) (Jan. 19, 2015), available at http://tfs. mofcom.gov.cn/article/as/201501/20150100871010.shtml.

29. Huining Ling, On the Concept of 'Control' in Foreign Investment Law (draft for comments) -Take Protocol Control as an Example [论《论外国投资法 (草案征求意见稿) 中的“控制” 概念 -以协议控制模式为例》], Bus. [商] 233 (2016).

30. See the regular news conference of Commerce Department of China on August 2, 2016, If 1; Danyang Shen, the spokesman of the Commerce Department mentioned that more than $90 \%$ of the foreign invested enterprises were established through the registration and recording system, available at http://www.mofcom.gov.cn/article/ae/slfw/201608/ 20160801370615.shtml.

31. Supra note 27.

32. Zhen Cao, Reflection and Reconstruction of Foreign Investment Legal System in China [我 国外商投资法律体系反思与重构] 30 J. ChANGZHOU U. (Soc. SCI. ED.) [常州大学学报: 社会科 学版] 31 (2015).

33. Ningning Zhu, Improving the Socialist Legal System with Chinese Characteristics with the Constitution as the Core-Analyzing the Legislative Work Plan of the Standing Committee of the National People's Congress in 2018, People's Cong. China (2018). 
34. See the Legislative Work Plan of the Standing Committee of the National People's Congress for 2018, available at http://www.npc.gov.cn/npc/c30834/201804/1c1b907 0eb574282b8ef6d2f33615383.shtml. The review for the Foreign Investment Law was arranged to be accomplished in December 2018.

35. See the notification of the National People's Congress of the People's Republic of China, available at http://www.npc.gov.cn/npc/c12816/201812/9d961a37778b40418bc694f5a3 84b517.shtml.

36. The Foreign Investment Law includes 42 articles, 27 articles of which are for the promotion and protection of the foreign investment. While the management issues including the information report and security review only take 8 articles, available at http://www.npc.gov.cn/npc/c30834/201903/121916e4943f416b8b0ea12e0714d683.shtml.

37. Supra note 35.

38. Wang Chen (vice chairman of the Standing Committee of the National People's Congress), Explanation to the Foreign Investment Law of People's Republic of China (Draft), Mar. 8, 2019, available at http://www.npc.gov.cn/npc/c30834/201903/e167985f 1a3a449b8815739326e3bd52.shtml.

39. Xiaojian Li, Flower's Fragrant Will Attract Butterfly- The Draft on Foreign Investment Law Will Be Submitted to the Second Session of the Thirteenth National People's Congress for Consideration, 2 People’s Cong. China XXX, 20 (2019).

40. Xiaojian Li, Preliminary Examination on the Draft of Foreign Investment Law: Widely Open the Gate of China, 1 People's Cong. China XXX, 27 (2019).

41. President Decree No. 26 of People's Republic of China (15 Mar. 2019), available at http://www.npc.gov.cn/npc/xinwen/2019-03/15/content_2083625.htm.

42. See the regular news conference of the PRC Department of Commerce on Dec. 27, 2018, available at http://www.mofcom.gov.cn/xwfbh/20181227.shtml. Gao Feng, the news spokesman of Commerce Department answered the question of the journalist from National Business Daily.

43. Foreign Investment Law art. 42.

44. Id.

45. See the Interview to Guo Xinming, the representative of the 'Two Sessions,' Enforcement Regulations for the Foreign Investment Law are needed to be Formulated, available at http://www.financialnews.com.cn/zt/2019lh/lhft/201903/t20190315_156369.html.

46. Foreign Investment Law art. 2.

47. PRC Ministry of Commerce and PRC National Development and Reform Commission, 'Decree No. 18' (2018), available at http://www.mofcom.gov.cn/article/b/f/201806/ 20180602760432.shtml.

48. National Development and Reform Commission of the People's Republic of China, The Notification of the Negative List of Market Access (2018 Edition), available at http:// www.ndrc.gov.cn/zcfb/zcfbtz/201812/t20181228_924067.html. 
49. See the explanation part of the Negative List of Market Access (2018 edition): articles 1, 4 and 6, available at http://images.mofcom.gov.cn/wzs/201806/20180628220738627.pdf. 50. Foreign Investment Law art. 9.

51. Id. art. 10.

52. Id. art. 11.

53. Id. art. 16.

54. Id. art. 17.

55. Id. art. 19.

56. Id. art. 20.

57. Id. art. 21.

58. Id. art. 22.

59. Zhe Mou, A Comparative Study of Foreign Investment Enterprise Law and Foreign Investment Law (draft for comments) [外商投资企业法与外国投资法 (征求意见稿) 之比较 研究], Bus. [商], Sept. 2, 2015, at 234.

60. Foreign Investment Law art. 23.

61. Id. art. 24.

62. Id. art. 25.

63. Id. art. 26.

64. Id. art. 27.

65. Id. art. 28.

66. Jingjing Tang, Study on the Improvement of the Legal System of 'Negative List' in China's Investment Field [我国投资领域“”负面清单” 法律制度完善研究], J. GANSU PoL. SCI. \& L. INST. [甘肃政法学院学报] XXX, 151 (2017).

67. Foreign Investment Law art.30. ๆ 1.

68. Id. art.31.

69. Id. arts. 29-32.

70. $I$ d. art. 34, $\uparrow \uparrow 1-2$.

71. Id. art.34. $\llbracket 1$.

72. Id. art. $34, \mathbb{} 2$.

73. Id. art. 35 .

74. Id. art. 8.

75. Id. art. 40 .

76. Id. art. 41.

77. Id. art. 1.

78. Id. art. 1.

79. On November 17, 2018, Chinese President Xi Jinping attended the APEC Business Leaders' Summit in Port Moresby, the capital of Papua New Guinea, and delivered a keynote speech entitled 'Together to Create a Better Future'. Xi said that China will continue to significantly relax market access, strengthen intellectual property protection 
and take the initiative to expand imports. China has issued a new negative list of foreign investment access and has opened up further in the fields of finance, automobiles, aircraft and ships. China treats foreign and domestic enterprises equally, welcomes and encourages fair competition among all kinds of enterprises, and intends to safeguard fully their legitimate rights and interests. Xi Jinping, Together to Create a Better Future (Nov. 2018), available at http:/www.xinhuanet.com/politics/leaders/2018-11/17/ c_1123728402.htm.

80. See The Publication of Foreign Investment Law, Implementing the Management System of Pre-entry National Treatment plus Negative List to Foreign Investment, the report from Nansha New Area on Mar.22, 2019, available at http://www.gznsnews.com/index. $\mathrm{php} ? \mathrm{~m}=$ content $\& \mathrm{c}=$ index $\& \mathrm{a}=$ show $\&$ catid $=8 \& \mathrm{id}=44063$.

81. Shaohua Sun, Wenbo Wang, Deng Liu \& Jian Yang, Foreign Investment Law, Highlighting the Spirit of Fair Competition [外商投资法推进我国高水平对外开放], 11 ECON. INFO. DAILY [经济参考], Mar. 11, 2019.

82. Foreign Investment Law art. $35, \llbracket 2$.

83. "Delegation, supervision and service" refers to simplifying government control, decentralizing power and optimizing service. 'Delegation' means simplifying administration, decentralizing power and lowering access threshold. 'Management' means fair supervision and promotion of fair competition. 'Service' means efficient service to create a convenient environment of business.

84. See the answer to reporters' request by Gao Feng, Spokesman of the Ministry of Commerce, Regular Press Conference (Dec. 27, 2018), available at http://www.mofcom. gov.cn/xwfbh/20181227.shtml.

85. Article 42 stipulates the five-year transition period for those foreign-invested enterprises established before the implementation of the Foreign Investment Law. While this time allows these enterprises to keep their original organizational forms, detailed implementation regulations need to be promulgated in the near future.

86. The Foreign Investment Law generally stipulates that the forms of organization of foreign-invested enterprises shall be governed by the Company Law and the Partnership Enterprise Law. In terms transition period, there is no detailed provision.

87. The Foreign Investment Law stipulates the five-year transition period but does not mention how the transition period should be regulated or what will happen if those enterprises cannot complete the transition within the given period. Detailed implementation measures shall be prescribed by the State Council in the near future.

88. According to Article 31 of the Foreign Investment Law, forms of organization, organization structures and activities of foreign-invested enterprises should be governed by the provisions of the Company Law and the Partnership Enterprise Law. Foreign-invested enterprises need to adjust the above mentioned things according to the Company Law or the Partnership Enterprise Law. Related provisions can be found in chapters 3 and 4 of 
the Company Law and in chapters 2-4 of the Partnership Enterprise Law. For details, see Annex 1.

89. Company Law ch. 5.

90. Xiuping Yang, A Comparative Analysis of the Protection Measures of Shareholders' Rights and Interests in Chinese and Foreign Management [中外管理层收购股东权益保护 措施的比较分析], H.L.J. Foreign ECon. Rel. \& TRADE [黑龙江对外经贸] XXX, 61 (2005).

91. For example, Article 3 of the Law on Sino-Foreign Equity Joint Ventures stipulates that "the equity joint venture agreement, contract, and articles of association signed by the parties to the venture shall be submitted to the state's competent department...," which means that the contract mentioned here has the same position as the articles of association. But after the law's being abolished, the contract will lose this position.

92. Law on Sino-Foreign Contractual Joint Ventures arts. $21 \& 22$.

93. Id.

94. According to Article 81 of the Company Law, the profit distribution of a company should be stipulated in its articles of association; that is to say, it is not necessary to distribute profits according to the proportion of capital contribution.

95. Article 186 of the Company Law stipulates that the residual property that results from paying off the liquidation expenses, wages of employees, social insurance premiums and legal compensation premiums, outstanding taxes and debts of the company may, in the case of a limited liability company, be distributed according to the proportions of capital contributions of the shareholders, and, in the case of a joint stock limited company, according to the proportions of stocks held by the shareholders.

96. W. Mallesons et al., Entering into the Era of Foreign Investment Law, the Changes and Challenges of the Legal Practice in the Field of Foreign Investment [进入《外商投资法》时代 -外商投资法律实务的变化与挑战], Mar. 22, 2019, available at https://www.pkulaw.com/ la wfirmarticles/592ce5166ae2fc90d3e9fbcd2784f8f9bdfb.html.

97. Shengle Zhou, Concept and Problems of Registered Capital, Total Investment and Guarantee Liability of Sino-foreign Joint Ventures [中外合资企业注册资本、投资总额与保证责任的含 义及问题], INT'L Bus. Res. [国际商务研究] 32 (1986).

98. Yanhua Zou, Reflections on Improving the Management of 'Difference between Investment and Registered Investment' in Foreign Debt of Foreign-funded Enterprises [对完善外商投资 企业外债“”投注差” 管理的思考], CHINA FOREX [中国外汇] 71 (2006).

99. Bank of China, No. 9. Notice of the People's Bank of China on the Macro-Prudential Management of Full-caliber Cross-border Financing (2017), available at http://zfxxgk.weihai. gov.cn/xxgk/jcms_files/jcms1/web81/site/attach/-1/171108165003041.pdf.

100. Id. art. 13.

101. Jinyong Wu, Discussion on Perfecting Macro-Prudential Management of Foreign Debt of Foreign-funded Leasing Companies [完善外资租赁公司外债宏观审慎管理的探讨], FUJIAN FIN. [福建金融] 61 (2018). 
102. Foreign Investment Law art. 4, $₫ 4$.

103. See The Third Review of the Draft for Foreign Investment Law: Amendment for the Articles about International Treaty, the report of the Xinjing Newspaper on Mar. 8, 2019, available at $\mathrm{https}$ ://baijiahao.baidu.com/s?id=1627450788534126361\&wfr=spider \&for $=$ pc

104. See Publication of the Foreign Investment Law, the Pragmatic Amendment is Getting Positive Comments, the report of China Business News on Mar. 17, 2019, available at https://www.yicai.com/news/100141058.html.

105. Foreign Investment Law art. 31.

106. Id. art. 42.

107. Before the implementation of the Foreign Investment Law, a large number of provisions of the three laws on foreign-invested enterprises focused on the form of organization and the code of conduct. In recent years, with the development of the modern enterprise system in China, the Company Law and Partnership Enterprise Law have been promulgated for the organization and behaviour of enterprises. In view of the norms of enterprise organization and behaviour, the three laws on foreign-invested enterprises have formed a dual-track system with the Company Law and the Partnership Enterprise Law inside and outside. After the implementation of the Foreign Investment Law, the supervision measures for the foreign-invested enterprises will be unified with the Company Law and the Partnership Enterprise Law because the three laws on foreigninvested enterprises will be repealed.

108. Xiaoxia Zhang, The Conflict and Integration between the Foreign Investment Law and the Company Law [论外商投资法与公司法的冲突和融合], 12 RULE BY L. \& Soc'y [法制与 社会] 27 (2012).

109. According to the three laws on foreign-invested enterprises, the highest authority of Sino-foreign equity joint ventures is the board of directors; the highest authority of Sinoforeign contractual joint ventures is the joint management committee; and the highest authority of foreign-funded ventures is the shareholder meeting or capital holders. After the implementation of the Foreign Investment Law, they need to change the highest authority to the shareholder meeting.

110. The Foreign Investment Law stipulates a five-year transition period, but there are no provisions about the measures for the delay in the adjustment and transition. See Foreign Investment Law art. 42.

111. Id. art. 33.

112. Article 31 of the Anti-Monopoly Law stipulates that 'for participation in concentration of business operators by way of foreign-funded merger and acquisition of domestic enterprises or any other method which involves national security, the examination of concentration of business operators shall be carried out pursuant to the provisions of this Law and examination of national security shall be carried out pursuant to the relevant 
provisions of the State.'

113. Foreign Investment Law art. 34, $\uparrow 2$.

114. Since 30 June 2018, the acceptance system of 'single window, single form' for business record and business registration for foreign-invested enterprises has been implemented nationwide to realize 'more information transmission, less errands for enterprises' and to enhance the sense of acquisition of foreign-invested enterprises.

115. The second paragraph of art. 34 of the Foreign Investment Law stipulates : "The content and scope of the foreign investment information report shall be determined in accordance with the principle of necessity; the investment information that can be obtained through the inter-department information sharing system shall not be required to be submitted again."

116. State Department Office, No. 6 (2011), available at http://www.gov.cn/zwgk/2011-02/ 12/content_1802467.htm.

117. State Department Office, No. 24 (2015), available at http:/www.gov.cn/zhengce/content/ 2015-04/20/content 9629.htm.

118. Foreign Investment Law art. 35.

119. Foreign Investment Law (Draft for Comment 2015), available at http://www.mofcom. gov.cn/article/ae/ag/201501/20150100871007.shtml.

120. Shuwen Chen, Analysis and Suggestions on the Foreign Investment Law [对《外商投资法》 草案的评析与建议], 1 Legal System \& SoC'y [法制与社会] 22 (2016).

121. Ying Jiang, The Foreign Investment Law of People's Republic of China is undertaking more Expectation: the exclusive interview of CPPCC to the committee member (Mar. 11, 2019-03), available at http://www.cppcc.gov.cn/zxww/2019/03/11/ARTI1 55226 7805499597.shtml.

122. See the speech of Gao Feng, Spokesman of Commerce Ministry, Regular Press Conference (Mar. 21, 2019), available at http://www.mofcom.gov.cn/xwfbh/20190321. shtml.

123. Id.

124. Yao Lu, Bichang Zhang \& Xinyun Guo, Analysis on the Equal Treatment Principle of the Foreign Investment Law of People's Republic of China [浅议《中华人民共和国外商投资法》 的平等对待、内外一致原则], Perspective OF LAWYer [律师视角], Mar. 9, available at http://www.allbrightlaw.com/CN/10475/d6da2ba19c9a7d5e.aspx.

125. See the speech of Liu Xiaoyun, deputy to the National People's Congress and President of Shanghai Higher People's Court, Plenary Meeting of the Shanghai Delegation at the Second Session of the Thirteenth National People's Congress, available at http://www. sohu.com/a/300358811_289260.

126. Jianping Yin, Zhang Ting, Analysis on the Regulation of Abuse of Market Dominance in Antitrust Law [反垄断法中滥用市场支配地位规制浅析], ForeIGN InV. CHINA [中国外资] 82-4 (2008). 
127. See the related part of speech of Liu Xiaoyun, the president of the Shanghai Higher People's Court at the Second Session of the Thirteenth National People's Congress, available at http://www.ctoutiao.com/1482195.html.

128. Id.

129. The "one bank, two committees" refers to the People's Bank of China, China Banking Insurance Regulatory Commission and China Securities Regulatory Commission.

130. The "one network operation" refers to the collection of data into a functional platform. As long as an enterprise enters one door, it can accomplish matters in different fields and solve problems, such as "endless procedures, endless permissions and endless forms."

131. See the speech of Fan Yun, Deputy to the National People's Congress, at the Plenary Meeting of the Shanghai Delegation at the Second Meeting of the Thirteenth National People's Congress.

132. See the remarks made by Premier Li Keqiang of the State Council during his interview with Chinese and foreign journalists. Li Keqiang, Premier of the State Council, Second Session of the Thirteenth National People's Congress in the Great Hall of the People (Mar. 15, 2019), available at http://www.xinhuanet.com/politics/2019-03/15/ c 1124237105. htm.

133. See the speech of President Xi Jinping at the Opening Ceremony of the First China International Import Expo (2018), available at http://www.xinhuanet.com/world/ ciie2018/jbhkms/index.htm. 
